\title{
Combined multi-criteria decision making and system dynamics simulation of social vulnerability in southeast Asia
}

\author{
Amarulla Octavian ${ }^{a}$, Jobi Widjayanto ${ }^{a}$, I Nengah Putra ${ }^{a}$, Susilo Adi Purwantoro ${ }^{\text {, }}$, Mohd Zaini \\ Salleh $^{\mathrm{b}}$, Azrul Azlan Abd Rahman ${ }^{\mathrm{b}}$, Ariffin Ismail ${ }^{\mathrm{b}}$ and Rogis Baker ${ }^{\mathrm{b}}$
}

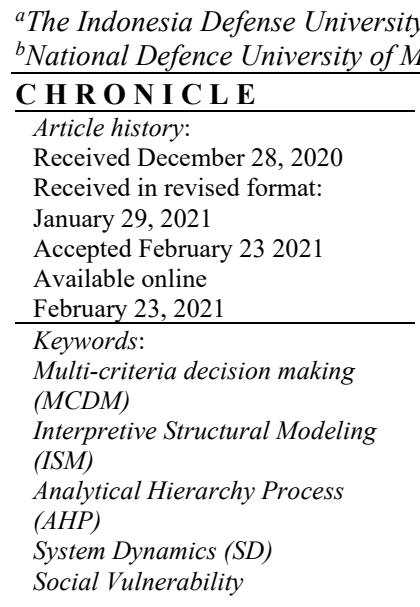

System Dynamics (SD)

Social Vulnerability

\section{A B S T R A C T}

The development of the Islamic State (IS) in Southeast Asia creates changes in the social order in a direct and indirect manner. This study aims to identify the factors that influence the development of the Islamic State (IS) and analyze the influence of its development on social vulnerability in Southeast Asia. This study employed a mixed-method supported by the Interpretive Structural Modeling (ISM), Analytical Hierarchy Process (AHP), and System Dynamics (SD). Based on the results of research from relevant experts, this study uncovered seven the most dominant and structured problems. Furthermore, there are fourteen elements related to the social vulnerability of the Islamic State (IS) in Southeast Asia. The social vulnerability value is 0.01 and is categorized as Low Vulnerability. The aspects that influence the development of Islamic State indicate that the existing social system in Southeast Asia is strong enough in encountering the influence of ideology and the development of the Islamic State.

\section{Introduction}

The decision-making system is designed to support all stages of decision making from problem identification, selecting relevant data, determining the approach used in the decision-making process, to selecting alternative choices (Calabrese, et al., 2019). Multi-criteria decision making (MCDM) always considers weighting considerations to determine alternatives from the various available criteria. Multi Criteria Decision Making (MCDM) is a method of decision making to determine the best alternative from a number of alternatives based on certain criteria (Kumar, et al., 2017). Criteria are usually in the form of measures or rules or standards used in decision making (Medineckiene, et al., 2015). The system dynamic is a methodology for studying problems around the view of the problem as a whole (holistically) (Enteshari \& Safavi, 2021). The main concept of dynamic systems is the understanding of how all objects in a system interact with each other (Khakbaz \& Hajiheydari, 2015). Furthermore, this method is illustrated as a simulation to understand the dynamics of complex learning management, understand the source of barriers in policy and design more effective policies (Improta, et al., 2018). The development of the Islamic State (IS) in Southeast Asia creates changes in the social order a direct and indirect manner (Tome, 2015). This certainly affects the action and activity patterns of society in various aspects, including social aspects. This social condition is expected to clarify the existing strategic situation in Southeast Asia (Tobing \& Indradjaja, 2019). To date, the extent to which the influence of the development of the Islamic State (IS) affects social vulnerability in Southeast Asia has not been established. It is considered important to identify any factors related to this social condition along with the social vulnerability analysis (Belim \& Garcia, 2016).

* Corresponding author.

E-mail address: nengahputra35@gmail.com (I.N. Putra)

(C) 2021 by the authors; licensee Growing Science, Canada. doi: $10.5267 /$ j.dsl.2021.2.005 
This study aims to identify the factors that influence the development of the Islamic State (IS) and analyze the influence of its development on social vulnerability in Southeast Asia. This study employed a mixed-method supported by the Interpretive Structural Modeling (ISM), Analytical Hierarchy Process (AHP), and System Dynamics (SD). The interpretive structural modeling provided an analysis of the relationship between criteria. The analytical hierarchy gave weight to the criteria. The system dynamics modeling provided an analysis of the simulation of the social vulnerability of Southeast Asian societies. Several previous studies are in support of this research. They are entitled "Development of a tourism conceptual model for the identity of the city of Bandung" (Adianto, et al., 2020), "ISM for navy development strategy" (Susilo, et al., 2019), "ISM for sustainable rural development" (Panackal \& Singh, 2016), "ISM for green supply management" (Dubey, et al., 2015), "Data analysis method of terrorist attacks based on AHP-DBSCAN metho" (Wang, et al., 2019), "AHPTOPSIS Model to Evaluate Maintenance Strategy using RAMS and Production Parameters" (Bona \& Falcone, 2019), "Improved AHP-TOPSIS model for the comprehensive risk evaluation of oil and gas pipelines" (Wang \& Duan, 2019), "Implementation of AHP and TOPSIS method to determine the priority of improving the management of government's assets" (Febriansyah, et al., 2017), "Group Decision-Making Using Improved Multi-Criteria Decision Making Methods for Credit Risk Analysis" (Wua, et al., 2016), "Modeling dynamic systems with efficient ensembles of process-based models" (Simidjievski, et al., 2016), "System dynamics modelling and simulating the effects of intellectual capital on economic growth" (Beran, 2015), "A system dynamics model for simulating the logistics demand dynamics of metropolitans: A case study of Beijing, China" (Qiu, et al., 2015), and "Simulation of dynamics behaviors for shipping equipment support with system dynamics analysis approach" (Song \& Yang, 2015).

This study was limited to the social vulnerability as a result of the development of Islamic State terrorism in the Southeast Asian region. This study analyzed and revealed the aspects of social vulnerability in Thailand, Malaysia, the Philippines, and Indonesia. This study is expected to shed some light on input in taking strategic plannings Southeast Asia. This study is also expected to contribute to the operations research and social development analysis in society.

This study comprises several parts. Section two describes social vulnerability, dimensions of social vulnerability, interpretive structural modeling (ISM), analytical hierarchy process (AHP), system dynamics model, research stages, and research instruments. Section three presents the results of social vulnerability analysis. Lastly, section four concludes the study.

\section{Materials and methods}

\subsection{Social Vulnerability}

Social vulnerability is a by-product of social inequality. Social vulnerability is defined as the vulnerability of social groups to the impact of hazards, as well as their resilience, or ability to adequately recover and social dynamics rooted in gender, class, race, culture, nationality, age, and other power relations (Papathoma-Köhle, et al., 2011). Social vulnerability is influenced by various factors. Social class is one of the biggest contributors leading to social vulnerability. This includes livelihood (type and stability), income, savings, education levels, settlement quality (house type and construction, infrastructure, and life path), type of ownership, built environment, family structure, population growth, commercial and industrial development, medical services, and residents with special needs. Those are the major components of social vulnerability, especially in combination with other marginalized (and these factors have an influence on economic losses, injuries, and deaths from natural disasters (Chen, et al., 2013). The idea of social vulnerability, as opposed to the structural vulnerability, refers to the potential harm to people. It refers to "the characteristics of a person or group in terms of their capacity to anticipate, cope with, resist, and recover from the impacts of natural hazard". It involves a combination of factors that determine the extent to which a person's life and livelihoods are threatened by different and identifiable events in nature or society. It has resulted from social inequalities and historical patterns of social relations as the deeply embedded social structural barriers that are resistant to change. Vulnerability is "embedded in complex social relations and processes" and is best viewed as a social problem requiring social solutions. The solution demands addressing how complex the problem really is, because it's not just a storm approaching or an earthquake shaking the ground. Instead, the problem stems from the "interface of society and environment" that is a pre-existing condition (Emrich \& 2011, 2011).

Social vulnerability is more than just the possibility of buildings to collapse or infrastructure to be damaged. Social vulnerability is described as a set of characteristics that includes a person's initial well-being (nutritional status, physical and mental health), livelihood and resilience (assets and capital, income and qualifications), self-protection (ability and willingness to build a safe house, using safe sites), social protection (preparedness and mitigation measures), and social and political networks and institutions (social capital, institutional, environmental, and the like) (Burton \& Cutter, 2008).

\subsection{Dimensions of Social Vulnerability}

Dimensions of vulnerable social groups include (Emrich \& 2011, 2011): a) Poverty; b) Class/ Caste; c) Race/ Ethnicity; d) Religion; e) Gender; f) Age such as the elderly ( $>65)$, the children ( $<5)$; g) Disabilities; h) Health; i) Language/ Literacy; j) Households and families, such as households with single parents. 
Dimension of Social Vulnerability (Cutter, et al., 2003):

a. Level of poverty.

b. Lack or limited access to resources such as information, knowledge, and technology.

c. Lack of or limited access to political power and representation (marginalization, exclusive)

d. Lack of or limited social capital including social networks and connections

e. Inadequate beliefs, customs and attitude in response to risk or disasters

f. Vulnerable residential settings (i.e. Weak structure, poor protection, poor maintenance, etc.)

g. Lack of or Limited access to critical services such as communication, transportation, power supply, water supply, sanitation, etc.

\subsection{Interpretive Structural Modelling (ISM)}

Interpretive structural modeling (ISM) was first proposed by J. Warfield in 1975 to analyze systems of high complexity and find solutions to complex problems or involve many interacting factors (Abdullah, et al., 2014). ISM is an interpretive method that generates solutions for complex problems through discourses based on structural mapping of the interrelationship of complex elements. ISM organizes several parts of complex problems, makes a model for decision making and simplifies planning on finding solutions to problems. Interpretive structural modeling is very flexible to use hundreds of elements. There is nothing that limits the types of methods used in analyzing these problems (Dubey, et al., 2015). Interpretive structural modeling can be used to perform program analysis in accordance with the vision and mission. Broadly, the techniques of interpretive structural modeling are divided into two, namely element classification and hierarchical arrangement. The first step in the ISM analysis is to determine the elements that correspond to the existing problems. Next, sub-elements are arranged for each selected element. The selection of elements and arrangement of subelements are carried out based on the results of discussions with experts. The results are arranged in a Structural Self Interaction Matrix (SSIM) in the form of a Reachability Matrix (RM) table by replacing V, A, X, O into numbers 1 and 0 . The classification of elements is based on the Structural Self Matrix (SSM) made based on the VAXO system (Shahabi, et al., 2019):

Table 1

Reachability Matrix Role for ISM

\begin{tabular}{ccc}
\hline If the $(\mathbf{i}, \mathbf{j})$ entry in the SSIM is & Entry in the initial reachability matrix \\
\cline { 2 - 3 } V & $(\mathbf{i}, \mathbf{j})$ & $\mathbf{( j ,}, \mathbf{i})$ \\
$\mathrm{A}$ & 1 & 0 \\
$\mathrm{X}$ & 0 & 1 \\
$\mathrm{O}$ & 1 & 1 \\
\hline
\end{tabular}

The matrix that has met the transitivity was proceeded to get the reachability matrix, Driver Power (DP), and Dependence (D). The last stage was to group the sub-elements into four sectors (Susilo, et al., 2019) :

a. Weak driver-weak Dependent variables (AUTONOMOUS), variables are generally not associated with the system but may have a little relationship.

b. Weak driver-strongly Dependent variables (DEPENDENT), variables in this sector are generally dependent.

c. Strong driver-strongly dependent variables (LINKAGE), variables in this sector should be studied carefully since the interaction may have an impact and feedback on the system.

d. Strong driver-weak Dependent variables (INDEPENDENT), variables in this sector have a strong influence on the system and heavily determine the success of the program.

\subsection{Analytical Hierarchy Process (AHP)}

Analytical Hierarchy Process (AHP) is a method to solve a complex unstructured situation into several components in a hierarchical arrangement, by giving subjective values regarding the relative importance of each variable, and determining which variables having the highest priority to influence the results in that situation (Saaty T. L., 1980). The decision-making process is basically selecting the best alternative. It is such as conducting problem structuring, determining alternatives, assigning probability values for aleatory variables, determining values, time preference requirements, and specification of risks. Regardless of the width of the definable alternatives or the detailed assessment of the probability value, the limitation remaining pervasive is the basis for comparison in the form of a single criterion (Saaty \& Vasgas, 2006). 
MCDA tool that uses a hierarchical problem decomposition

Local priority weights from Pairwise Comparative method (PCM) of judgement

Global priority weight by hierarchic composition (additive synthesis)

(Saaty 1980)

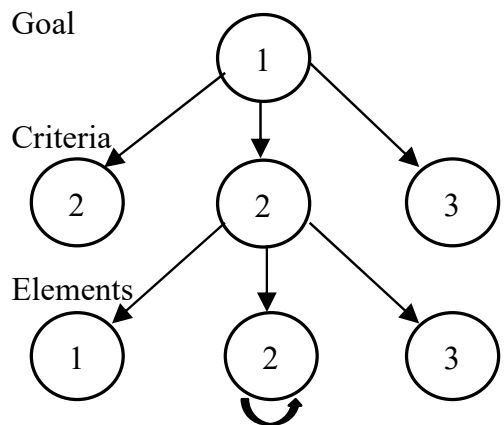

A loop indicates that each element depends only on itself
AHP follows a theory of relative measurement that provides:

(1) an 'objective' mathematics to model complexities of a problem, and

(2) a way to process 'subjective' preferences of groups/individuals in decision-making.

(Saaty, 1980)

Comparison is made between two alternatives based on a decision-maker's feeling of priority due to importance, preference and likelihood of influence

Fig. 1. Analytical Hierarchy Process (AHP) Model (Saaty T. L., 1990)

The main tool of the Analytical Hierarchy Process (AHP) is to have a functional hierarchy with the main input being human perception (Dekrita, et al., 2018). With a hierarchy, a complex and unstructured problem is solved in groups and arranged in a hierarchical form. Analytic Hierarchy Process (AHP) has an axiomatic foundation which consists of (Vachnadze, 2016):

a. Reciprocal Comparison, in which the formed pairwise comparison matrix must possess the contradictory character. For example, if $\mathrm{A}$ is $\mathrm{f}$ times more important than $\mathrm{B}$ then $\mathrm{B}$ is $1 / \mathrm{f}$ times more important than $\mathrm{A}$.

b. Homogeneity, which means similarity performing comparisons. For example, it is impossible to compare oranges to tennis balls in terms of taste, but it is more relevant in terms of weight.

c. Dependence, meaning that each level has a connection (complete hierarchy) although it is possible there is an imperfect relationship (incomplete hierarchy).

d. Expectation, which means raising expectations and preferences in decision making. Assessment can be quantitative data or qualitative data.

LEVEL 1 Goal

LEVEL 2 Criteria and sub-criteria

LEVEL 3 Altermnative

\begin{tabular}{|c|c|c|c|}
\hline \multicolumn{4}{|c|}{ Goal } \\
\hline Criteria 1 & Criteria 2 & ....... & Criteria n \\
\hline Sub-Criteria & Sub-Criteria & ....... & Sub-Criteria \\
\hline Alternative 1 & Alternative 2 & & Alternative 3 \\
\hline
\end{tabular}

Fig. 2. Hierarchy Model in AHP (Vachnadze, 2016)

The stages of decision making in the AHP method are basically as follows (Saaty \& Vasgas, 2006):

a. Defining the problem and determining the desired solution.

b. Creating a hierarchical structure starting with a general goal, followed by the criteria and options that you want to rank for.

c. Forming a pairwise comparison matrix describing the relative contribution or influence each element to each objective or criterion level above it. Comparisons are made based on the choice or judgment of the decision maker in assessing the level of importance of an element compared to other elements.

d. Normalizing data is by dividing the value of each element in the paired matrix by the total value of each column.

e. Calculating the eigenvector value and testing its consistency. If it is not consistent, the data retrieval (preference) needs to be repeated. The eigenvector value in question is the maximum eigenvector value obtained by using Matlab or manually.

f. Repeating steps 3, 4, and 5 for all levels of the hierarchy.

g. Calculating the eigenvector of each paired comparison matrix. The eigenvector value is the weight of each element. This step is to synthesize options prioritizing elements at the lowest level of the hierarchy until the achievement of goals.

h. Testing hierarchy consistency. If it does not comply with $\mathrm{CR}<0,100$, the assessment must be repeated.

Research objectives and procedures are described in formula :

a. $\quad$ Make a Pair Comparison Matrix (Wang \& Duan, 2019). 


$$
A=a_{i m}=\left[\begin{array}{cccc}
1 & a_{12} & \ldots & a_{1 n} \\
\frac{1}{a_{12}} & 1 & \ldots & a_{2 n} \\
\ldots & \ldots & \ldots & \ldots \\
\frac{1}{a_{1 n}} & \frac{1}{a_{2 n}} & \ldots & 1
\end{array}\right]
$$

$$
\mathrm{i}, \mathrm{m}=1,2, \ldots \ldots, \mathrm{n}=\text { index } \text { of related criteria. }
$$

b. Make a Criteria Value Matrix.

c. Make an Addition Matrix for Each Line.

d. Calculation of Consistency Index (CI) and Consistency Ratio (CR).

$$
\begin{aligned}
& \mathrm{Cl}=\frac{\lambda m a k s-n}{n}, \\
& \mathrm{CR}=\frac{C I}{R I}
\end{aligned}
$$

$\mathrm{N}=$ Number of Elements,

$\mathrm{RI}=$ Random Consistency Index .

If the $\mathrm{CR}$ ratio $\leq 0.1$ (i.e. $10 \%$ ), the matrix is said to be consistent and the decision $\mathrm{W}$ is accepted. Conversely, $\mathrm{CR}$ more than that implies too many contradictions in the matrix. Anticipation for the final situation is to review the matrix, then revise the weights loaded by the vector.

\section{Table 1}

Random Index Value.

\begin{tabular}{ccccccccccc}
\hline $\mathbf{N}$ & $\mathbf{3}$ & $\mathbf{4}$ & $\mathbf{5}$ & $\mathbf{6}$ & $\mathbf{7}$ & $\mathbf{8}$ & $\mathbf{9}$ & $\mathbf{1 0}$ & $\mathbf{1 1}$ & $\mathbf{1 2}$ \\
\hline $\mathbf{R I}$ & 0.58 & 0.9 & 1.12 & 1.24 & 1.32 & 1.41 & 1.49 & 1.51 & 1.53 & 1.56 \\
\hline
\end{tabular}

(Saaty T. L., 1990)

\section{System Dynamics Model}

The System Dynamics Society offers an updated definition of System dynamics that SD is "a methodology for studying and managing complex feedback systems". The system dynamics were first introduced by Jay W. Forrester in the 1950s. It is a method of solving complex problems resulted from the causal tendency of various variables in the system. The system dynamics method was first applied to management problems such as inventory fluctuations, labor instability, and a decline in a market share. From the system dynamics in the form of a causal diagram, a flow diagram is built to describe the simulation variables, parameterization, as well as the model formulation for simulation (Forrester, 1994). The variables in system dynamics are described in

Table 2.

Table 2

The Symbols in System Dynamics Model.

\begin{tabular}{cl}
\hline Variable & \multicolumn{1}{c}{ Explanation } \\
Level & $\begin{array}{l}\text { Present the accumulated quantity accumulated over time, which can change } \\
\text { in value in line with changes in the rate }\end{array}$ \\
Auxiliary & $\begin{array}{l}\text { Presents the flow rate which can change the level value } \\
\text { the rate }\end{array}$
\end{tabular}

Source: (Sushil, 1993)

The System Dynamics model that represents the structure of the feedback diagram is a causal diagram or commonly known as a Causal Loop Diagram (CLD). This diagram shows the direction of the flow of change in the variables as well as their polarity. The flow polarity is divided into positive and negative. Another diagram that also describes the structure of a system dynamics is a flow diagram. Flow diagrams represent the relationships among variables in a causal diagram more clearly, using certain symbols for the various variables involved (Sushil, 1993). 
Causal Loop Diagram (CLD) is an image language that connects various variables in a loop diagram. Arrows show the variables that are caused and or effective. The arrowhead shows the cause, while the other side shows the effect. The processes that occur in the real world must be understood to create a logical model resembling reality. The understanding can be obtained by distinguishing the cause and effect variables and or by distinguishing the dependent and independent variables (Sterman, Henderson, Beinhocker, \& Newman, 2007).

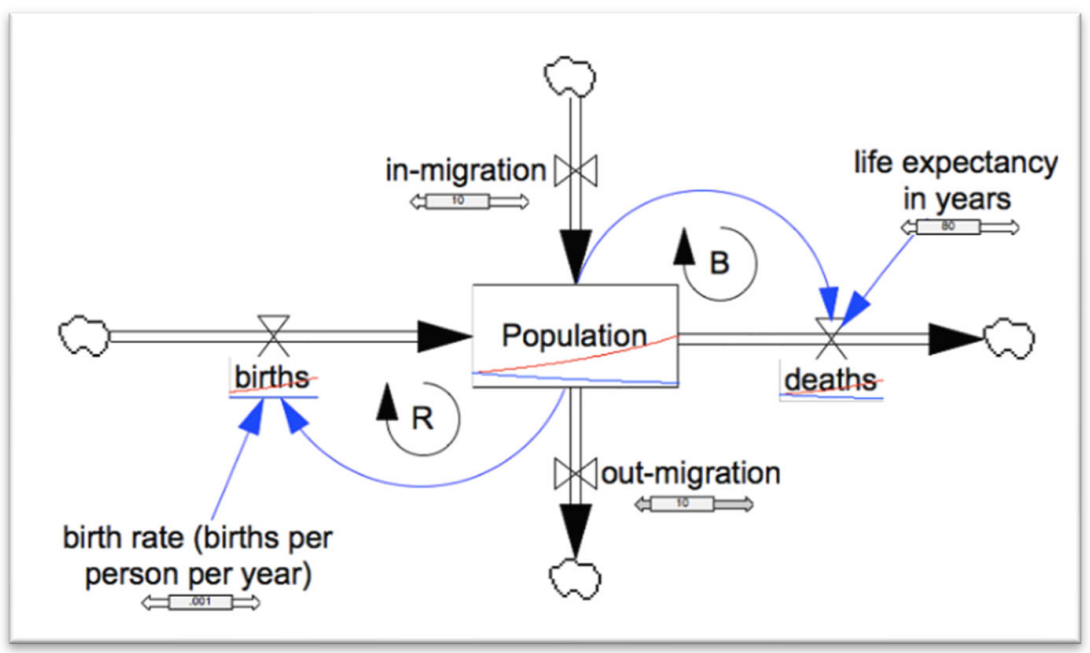

Fig. 3. System Dynamics Modelling

Sorce: (Qiu, et al., 2015)

\section{Research Stages}

The primary data sources in this study were the informants from the Ministry of Defense of the Republic of Indonesia, the Ministry of Foreign Affairs of the Republic of Indonesia, The Coordinating Ministry for Political, Legal, and Security Affairs, and other Ministries and institutions such as the Indonesian Ambassador to Thailand, Malaysia, the Philippines, and Indonesia as well as the ambassador and defense attaché of Thailand, Malaysia, The Philippines for Indonesia who are related to international cooperation of Politics and Security in anticipating the development of the Islamic State (IS) threat in Southeast Asia. The locus of this study is the Southeast Asia region, especially in four major countries including Thailand, Malaysia, the Philippines, and Indonesia. The informants who are interviewed were the officials who are directly related to the problems of the study.

Table 3

The Subjects of the Study.

\begin{tabular}{|c|c|c|c|}
\hline No & Subjects & Code & $\begin{array}{l}\text { Number } \\
\text { (people) }\end{array}$ \\
\hline 1 & $\begin{array}{l}\text { Director General of Asean Cooperation, the Ministry of Foreign Affairs of the } \\
\text { Republic of Indonesia }\end{array}$ & E1 & 1 \\
\hline 2 & $\begin{array}{l}\text { Director General of International Cooperation, the Directorate General of } \\
\text { Defense Strategy, the Ministry of Defense of the Republic of Indonesia }\end{array}$ & E2 & 1 \\
\hline 3 & $\begin{array}{l}\text { Director General of Strategic Analysis, The Directorate General of Defense } \\
\text { Strategy, the Ministry of Defense of the Republic of Indonesia }\end{array}$ & E3 & 1 \\
\hline 4 & $\begin{array}{l}\text { Director General of Defense Territory, the Directorate General of defense } \\
\text { strategy, the Ministry of Defense of the Republic of Indonesia }\end{array}$ & E4 & 1 \\
\hline 5 & $\begin{array}{l}\text { Deputy Minister for Foreign Affairs, the Coordinating Ministry of Politics, Law } \\
\text { and Security }\end{array}$ & E5 & 1 \\
\hline 6 & Ambassador/ defense attaché Thailand, Malaysia and Philipine & E6-E8 & 3 \\
\hline 7 & Indonesian Ambassador/ defense attaché Thailand, Malaysia and the Philiphines & E9-E11 & 3 \\
\hline 8 & The National Counter Terrorism Agency (BNPT) & E12-E15 & 4 \\
\hline 9 & The people of Thailand, Malaysia, the Philiphines, and Indonesia & E16-E35 & 20 \\
\hline
\end{tabular}

\section{Research Instruments}

This research used a case study starting with data collection in the form of words and pictures from texts, interviews, field notes, documents to provide clarity on the existing reality. 
The research instrument in this study comprises tools used to collect data for the research, both in qualitative and quantitative form. In this study, the data at the nominal level or nominal scale if the number serves for identification - distinguishing types of subjects. The difference in numbers only shows the separate and unequal objects or subjects. Meanwhile, the continuum data consists of data with ordinal scales, intervals, and ratios that are calculated based on the following scale:

Table 4

Scale and Level Analysis.

\begin{tabular}{cccc}
\hline Likert Score & $\boldsymbol{p}$-values & Categories & Colors \\
\hline 1 & $0-1$ & Low vulnerability & \\
2 & $1.001-2$ & Medium vulnerability & \\
3 & $2.001-3$ & High vulnerability & \\
4 & $3.001-4$ & Very high vulnerability & \\
5 & $4.001-5$ & Maximum vulnerability & \\
\hline
\end{tabular}

(Hummell, et al., 2016); (Girasole \& Cannatella, 2017); (Aksha, et al., 2018)

This study used a case study approach for the collection of data in terms of words and pictures from texts, interviews, field notes, documents to be described to provide clarity on the existing reality. After the data has been obtained, the next step was to carry out the interview transcript to finding out the informants' answers. The answers were interpreted according to the theories and concepts to answer the research questions. Thus, conclusions can be drawn.

\subsection{Goal}

The objectives of this study are:

i. Identifying factors that influence the development of the Islamic State to social vulnerability in Southeast Asia.

ii. Analyzing the influence of the Islamic State development on social vulnerability in Southeast Asia.

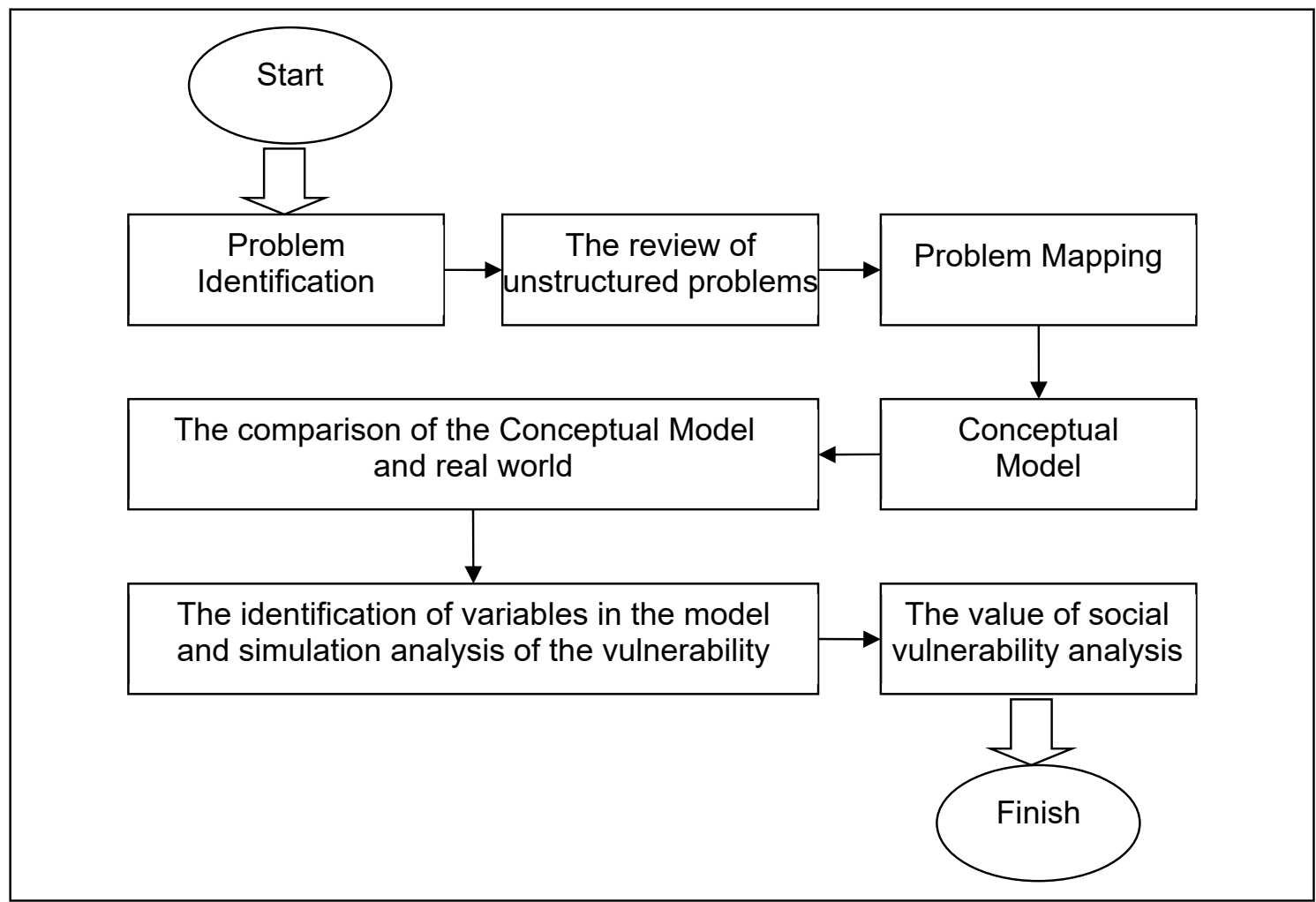

Fig. 4. The Flowchart of the Study.

\section{Result}

Previously, the analysis used the root definition to understand the current system and state "what it is". In this step, the results from the previous step were analyzed to answer "what should the system do". To achieve this goal, a conceptual model should be developed for each root definition. In this study, interpretive structural modeling was used to map the model. The first step was defining the elements: 
Territorial control

Terrorism

Budget capability

HR capabilities

Espionage
Law and regulations

Vessel traffic

Illegal transport

History of conflict

State borders
Human trafficking

Ease of financial access

The vulnerability of the democratic system

Corruption level

\subsection{Initial Reachability Matrix}

Interpretive structural modeling is a method for creating and understanding the relationships between elements of complex systems. ISM contributes greatly to managing complex relationships between system elements and help identify internal variable relationships.

Table 5

Elements of Social Vulnerability in the Development of the Islamic State (IS)

\begin{tabular}{|c|c|c|c|}
\hline Code & Elements & Code & Elements \\
\hline $\mathrm{C} 1$ & Territorial control & $\mathrm{C} 8$ & Law and regulations \\
\hline $\mathrm{C} 2$ & Terrorism & C9 & Vessel traffic \\
\hline $\mathrm{C} 3$ & Budget capability & $\mathrm{C} 10$ & Illegal transport \\
\hline $\mathrm{C} 4$ & HR capabilities & $\mathrm{C} 11$ & Human trafficking \\
\hline $\mathrm{C} 5$ & Espionage & $\mathrm{C} 12$ & Ease of financial access \\
\hline C6 & History of conflict & $\mathrm{C} 13$ & The vulnerability of the democratic system \\
\hline $\mathrm{C} 7$ & State borders & $\mathrm{C} 14$ & Corruption level \\
\hline
\end{tabular}

The second stage was the application of identifying criteria or variables that are defined in pairs. Using SSIM, paired relationships between the factors that affect the system were developed. The the incidence matrix was evaluated using SSIM and used for transitivity within the ISM. Next, factorization was carried out on the related criteria.

Table 6

SSIM on the Social Vulnerability Analysis

\begin{tabular}{|c|c|c|c|c|c|c|c|c|c|c|c|c|c|c|c|c|}
\hline \multirow{2}{*}{ No } & \multirow{2}{*}{ Code } & \multirow{2}{*}{ Factorization } & \multicolumn{14}{|c|}{ Factorization } \\
\hline & & & 14 & 13 & 12 & 11 & 10 & 9 & 8 & 7 & 6 & 5 & 4 & 3 & 2 & 1 \\
\hline 1 & $\mathrm{C} 1$ & Territorial control & $\mathrm{V}$ & $\mathrm{O}$ & $\mathrm{O}$ & $\mathrm{V}$ & $\mathrm{V}$ & $\mathrm{V}$ & $\mathrm{X}$ & $\mathrm{X}$ & A & A & A & $\mathrm{A}$ & $\mathrm{X}$ & \\
\hline 2 & $\mathrm{C} 2$ & Terrorism & $\mathrm{O}$ & $\mathrm{X}$ & $\mathrm{X}$ & $\mathrm{O}$ & $\mathrm{O}$ & $\mathrm{O}$ & $\mathrm{O}$ & $\mathrm{O}$ & $X$ & A & $X$ & $\mathrm{X}$ & & \\
\hline 3 & C3 & Budget capability & $\mathrm{O}$ & $\mathrm{O}$ & $\mathrm{X}$ & $\mathrm{O}$ & $\mathrm{O}$ & $\mathrm{V}$ & $\mathrm{O}$ & $\mathrm{O}$ & $\mathrm{O}$ & $\mathrm{O}$ & $\mathrm{O}$ & & & \\
\hline 4 & $\mathrm{C} 4$ & HR capabilities & $\mathrm{O}$ & $\mathrm{O}$ & $\mathrm{O}$ & $\mathrm{V}$ & $\mathrm{O}$ & $\mathrm{O}$ & V & $\mathrm{V}$ & $\mathrm{V}$ & $\mathrm{V}$ & & & & \\
\hline 5 & C5 & Espionage & $\mathrm{O}$ & $\mathrm{O}$ & $\mathrm{O}$ & A & $\mathrm{O}$ & $\mathrm{O}$ & $\mathrm{O}$ & A & $X$ & & & & & \\
\hline 6 & C6 & History of conflict & $\mathrm{O}$ & V & $\mathrm{O}$ & $\mathrm{O}$ & $\mathrm{O}$ & $\mathrm{O}$ & $\mathrm{X}$ & V & & & & & & \\
\hline 7 & $\mathrm{C} 7$ & State borders & A & $\mathrm{O}$ & $\mathrm{O}$ & A & A & $\mathrm{X}$ & $\mathrm{X}$ & & & & & & & \\
\hline 8 & $\mathrm{C} 8$ & Law and regulations & A & $\mathrm{V}$ & V & V & V & V & & & & & & & & \\
\hline 9 & $\mathrm{C} 9$ & Vessel traffic & $\mathrm{O}$ & $\mathrm{O}$ & $\mathrm{V}$ & A & A & & & & & & & & & \\
\hline 10 & $\mathrm{C} 10$ & Illegal transport & A & A & $\mathrm{O}$ & $\mathrm{O}$ & & & & & & & & & & \\
\hline 11 & $\mathrm{C} 11$ & Human trafficking & V & $\mathrm{O}$ & $\mathrm{O}$ & & & & & & & & & & & \\
\hline 12 & $\mathrm{C} 12$ & Ease of financial access & $\mathrm{O}$ & $\mathrm{O}$ & & & & & & & & & & & & \\
\hline 13 & $\mathrm{C} 13$ & $\begin{array}{l}\text { The vulnerability of the democratic } \\
\text { system }\end{array}$ & $\mathrm{X}$ & & & & & & & & & & & & & \\
\hline 14 & $\mathrm{C} 14$ & Corruption level & & & & & & & & & & & & & & \\
\hline
\end{tabular}

Table 7

Reachability Matrix of Social Vulnerability Analysis

\begin{tabular}{|c|c|c|c|c|c|c|c|c|c|c|c|c|c|c|c|c|}
\hline \multirow[t]{2}{*}{ No } & \multirow{2}{*}{ Code } & \multicolumn{14}{|c|}{ Factorization } & \multirow{2}{*}{ DP } \\
\hline & & 1 & 2 & 3 & 4 & 5 & 6 & 7 & 8 & 9 & 10 & 11 & 12 & 13 & 14 & \\
\hline 1 & $\mathrm{C} 1$ & 1 & 1 & 0 & 0 & 0 & 0 & 1 & 1 & 1 & 1 & 1 & 0 & 0 & 1 & 8 \\
\hline 2 & $\mathrm{C} 2$ & 1 & 1 & 1 & 1 & 0 & 1 & 0 & 0 & 0 & 0 & 0 & 1 & 1 & 0 & 7 \\
\hline 3 & $\mathrm{C} 3$ & 1 & 1 & 1 & 0 & 0 & 0 & 0 & 0 & 1 & 0 & 0 & 1 & 0 & 0 & 5 \\
\hline 4 & $\mathrm{C} 4$ & 1 & 1 & 0 & 1 & 1 & 1 & 1 & 1 & 0 & 0 & 1 & 0 & 0 & 0 & 8 \\
\hline 5 & $\mathrm{C} 5$ & 1 & 1 & 0 & 0 & 1 & 1 & 0 & 0 & 0 & 0 & 0 & 0 & 0 & 0 & 4 \\
\hline 6 & C6 & 1 & 1 & 0 & 0 & 1 & 1 & 1 & 1 & 0 & 0 & 0 & 0 & 1 & 0 & 7 \\
\hline 7 & $\mathrm{C} 7$ & 1 & 0 & 0 & 0 & 1 & 0 & 1 & 1 & 1 & 0 & 0 & 0 & 0 & 0 & 5 \\
\hline 8 & $\mathrm{C} 8$ & 1 & 0 & 0 & 0 & 0 & 1 & 1 & 1 & 1 & 1 & 1 & 1 & 1 & 0 & 9 \\
\hline 9 & C9 & 0 & 0 & 0 & 0 & 0 & 0 & 1 & 0 & 1 & 0 & 0 & 0 & 0 & 0 & 2 \\
\hline 10 & $\mathrm{C} 10$ & 0 & 0 & 0 & 0 & 0 & 0 & 1 & 0 & 1 & 1 & 0 & 0 & 0 & 0 & 3 \\
\hline 11 & C11 & 0 & 0 & 0 & 0 & 1 & 0 & 1 & 0 & 1 & 0 & 1 & 0 & 0 & 1 & 5 \\
\hline 12 & $\mathrm{C} 12$ & 0 & 1 & 1 & 0 & 0 & 0 & 0 & 0 & 0 & 0 & 0 & 1 & 0 & 0 & 3 \\
\hline 13 & C13 & 0 & 1 & 0 & 0 & 0 & 0 & 0 & 0 & 0 & 1 & 0 & 0 & 1 & 1 & 4 \\
\hline \multirow[t]{2}{*}{14} & $\mathrm{C} 14$ & 0 & 0 & 0 & 0 & 0 & 0 & 1 & 1 & 0 & 1 & 0 & 0 & 1 & 1 & 5 \\
\hline & & 8 & 8 & 3 & 2 & 5 & 5 & 9 & 6 & 7 & 5 & 4 & 4 & 5 & 4 & \\
\hline
\end{tabular}




\subsection{MICMAC Analysis}

The next step is to order a hierarchy for each sub-element in the element being studied and classify it into four sectors, namely Autonomous, Dependent, Linkage, or Independent sectors, namely:

a. Quadrant I: weak driver-weak dependent variables (Autonomous), the sub-elements in this sector are generally not related to the system and may have a little relationship even though the relationship can be strong

b. Quadrant II: weak driver-strongly dependent variables (dependent), the sub-elements in this sector are dependent.

c. Quadrant III: strong driver-strongly dependent variables (Linkage),

d. The sub-elements in this sector must be studied carefully because the relationship between the sub-elements are unstable.

e. Quadrant IV: Strong driver-weak dependent variables (Independent), the sub-elements in this sector are the remaining parts of the system or independent variables.

Table 8

Driving-Dependence Power Analysis on Social Vulnerability

\begin{tabular}{ccccccccccccccc} 
C1 & C2 & C3 & C4 & C5 & C6 & C7 & C8 & C9 & C10 & C11 & C12 & C13 & C14 \\
8 & 8 & 3 & 2 & 5 & 5 & 9 & 6 & 7 & 5 & 4 & 4 & 5 & 4 \\
8 & 7 & 5 & 8 & 4 & 7 & 5 & 9 & 2 & 3 & 5 & 3 & 4 & 5 \\
\hline
\end{tabular}

The results of the MICMAC diagram processing classified the elements into four sectors in a two-dimensional graph with the $\mathrm{x}$ (dependence) and $\mathrm{y}$ (powder driver) axes.

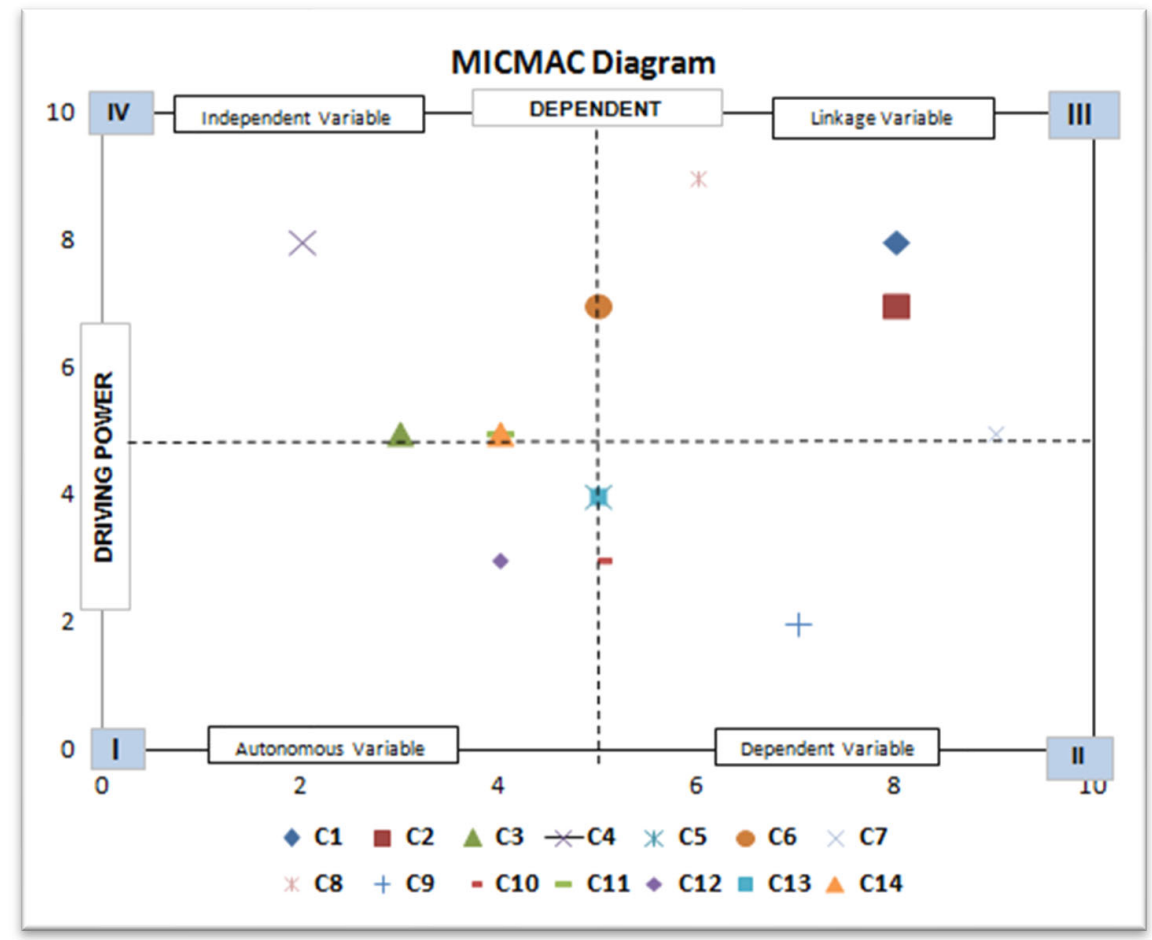

Fig. 5. Diagram of MICMAC Analysis of the Social Vulnerability of the Development of Islamic State (IS).

Fig. 5 depicts several classifications of elements on the influence of the development of the Islamic State (IS) on the social vulnerability in Southeast Asia. These elements are divided into four classifications:

a. Quadrant I (Autonomous) consists of the ease of financial access (C12)

b. Quadrant II (Dependent) consists of four elements: a) espionage (C5); b) vessel traffic (C9); c) Illegal transport (C10); d) the vulnerability of the democratic system (C13).

c. Quadrant III (Linkage) consists of five elements: a) territorial control (C1); b) terrorism (C2); c) history of conflict (C6); d) state borders (C7); e) law and regulations (C8).

d. Quadrant IV (Independent) consists of four elements: a) budget capability (C3); b) HR capabilities (C4); c) Human trafficking (C11); d) corruption level (C14). 
The influence of the development of the Islamic State (IS) on social vulnerability is a system. Thus, it has a network in it that involves complex variables and dynamics. System dynamics were used to draw models. The existing problems were examined by system dynamics modeling. A causal diagram was used to identify and highlight the dynamic relationships of the problem. The value of the influence of the development of the Islamic State (IS) on the social vulnerability of communities in Southeast Asia can be described in the form of a Stock-Flow diagram.

By understanding the system dynamics approach, it can be seen more clearly that the analysis of the influence of social vulnerability comprises of several elements that influence one another. The related elements need to be studied carefully since each unit can influence each other or have an impact on one another, especially those in Quadrant III and Quadrant IV. The elements of territorial control, state borders, and the law and regulation have a high influence in mobilizing other elements in the assessment of the influence of the development of the Islamic State (IS) on social vulnerability.

In the implementation of system dynamics analysis, a weighting model of the criteria resulted from the interpretation of the 14 criteria elements. The weighting was carried out using the AHP. Then the score was obtained through a 1-5 point Likert scale. These elements were made into a hierarchical model group in accordance with the relationship:

a. Territorial control

1) Terrorism

2) Budget capability

3) HR capabilities

4) Espionage

5) History of conflict

6) Extreme right-wing

7) Extreme left-wing b. Off-guard State Borders

1) Vessel Traffic

2) Illegal transport.

3) Human trafficking.

c. Law and Regulation

1) Ease of financial access

2) The vulnerability of the democratic system

3) Corruption level

Table 9

The weighting of Social Vulnerability Variables of Territorial Control

\begin{tabular}{|c|c|c|}
\hline Criteria & Weighting & Score \\
\hline Terrorism & 0.122 & 4.585 \\
\hline Budget capability & 0.286 & 3.865 \\
\hline HR capabilities & 0.240 & 4.310 \\
\hline Espionage & 0.183 & 3.665 \\
\hline History of conflict & 0.168 & 3.805 \\
\hline Evaluation & 1.000 & 4.046 \\
\hline
\end{tabular}

The weighting of the aspect of territorial control consists of five criteria, namely terrorism, budget capability, HR capabilities, espionage, and history of conflict. The budget capability criterion had the highest weight value of 0.286 with a score of 3.865. Terrorism criteria had the lowest value of 0.122 with a score of 4.585 .

\section{Table 10}

The weighting of Social Vulnerability Variables of State Borders

\begin{tabular}{|c|c|c|}
\hline$x^{2}$ & Weighting & Score \\
\hline Vessel Traffics & 0.490 & 2.430 \\
\hline Illegal transport & 0.198 & 3.445 \\
\hline Human trafficking & 0.312 & 4.410 \\
\hline Evaluation & 1.000 & 3.428 \\
\hline
\end{tabular}

The weighting of the aspect of the state border consists of three criteria, namely vessel traffic, illegal transport, and human trafficking. The vessel traffic has the highest weighting of 0.490 with a score of 2.430 . The Illegal Transport criterion has the lowest weighting of 0.198 with a score of 3.445 .

Table 11

The weighting of Social Vulnerability Variables of Law and Regulation

\begin{tabular}{|c|c|c|}
\hline Criteria & Weighting & Score \\
\hline Ease of financial access & 0.261 & 4.725 \\
\hline The vulnerability of the democratic system & 0.411 & 2.570 \\
\hline Corruption level & 0.328 & 3.850 \\
\hline Evaluation & 1.000 & 3.715 \\
\hline
\end{tabular}

The weighting of the aspect of Law and Regulation consists of three criteria, namely ease of financial access, democratic system, and level of corruption. Criteria for the democratic system had the highest weighting of 0.411 with a score of 2.570 . The criteria for ease of access to finance had the lowest weighting of 0.261 with a score of 4.725 . 
Table 12

The weighting of Social Vulnerability Variables of Social Vulnerability

\begin{tabular}{lcc} 
& Criteria & Weighting \\
\hline Territorial Control & Score & 0.264 \\
State Border & 4.046 & 0.329 \\
Law and Regulation & 3.428 \\
Evaluation & 3.715 & 0.407 \\
\hline
\end{tabular}

The weighting of the variable of social vulnerability threat consists of three criteria, namely territorial control, state borders, and law and regulation. The criteria for Law and Regulation had the highest weighting of 0.407 with a score of 3.715 . Territorial control criteria had the lowest weighting of 0.264 with a score of 4.046 .

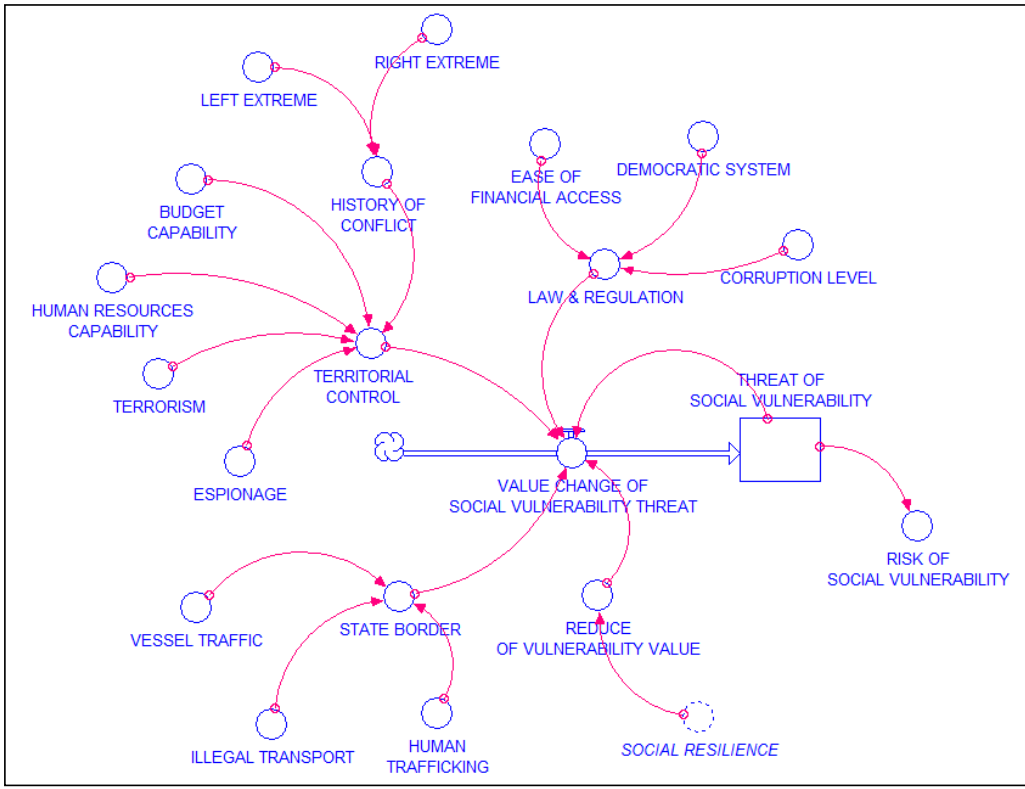

Fig. 6. Stock-flow diagram of the Influence of Islamic State (IS) Development on Social Vulnerability in Southeast Asia

System dynamics modeling of the influence of Islamic State (IS) development of social vulnerability in Southeast Asia was carried out by referring to the objectives and scenarios of each model. This scenario was assumed to be the result of a simulation without intervention or activities to strengthen the social system. This illustrates that the development of the Islamic State (IS) and its impact on vulnerability are closely related to territorial control, state borders, and existing laws and regulations in the countries in the Southeast Asia. Model development is carried out to determine the behavior patterns and the relationship among the variables that determine the suitability of the model with reality. Using the modeling, the social vulnerability value of the Southeast Asian community can be analyzed. The simulation of system dynamics modeling was performed using Stella.

\subsection{Social Vulnerability Value of the Influence of Islamic State Development}

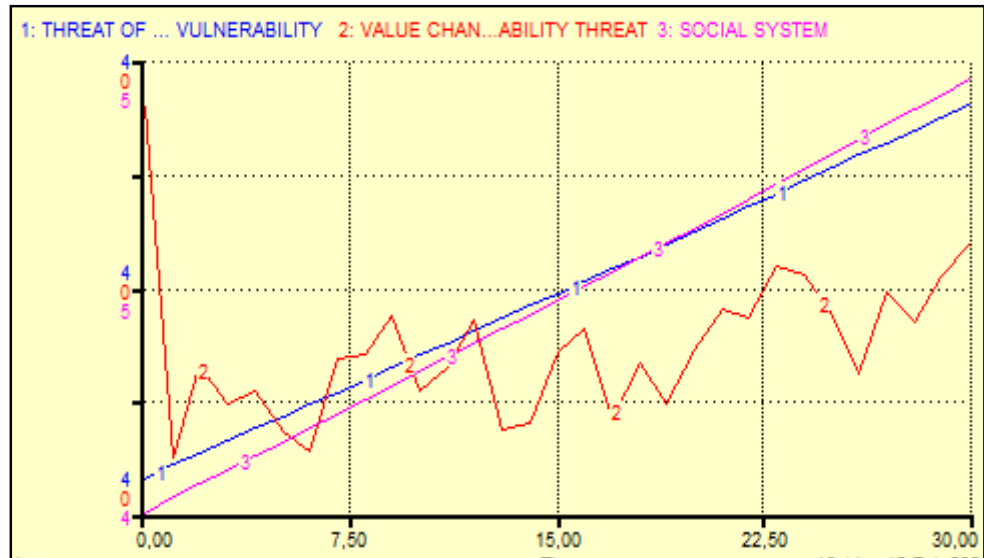

Fig. 7. The Influence of Islamic State Development on Social Vulnerability 
Table 13

Influence on Islamic State Development on Social Vulnerability.

\begin{tabular}{llll}
\hline Time & Threat of social value & Value change of Scoial value & Social system \\
\hline 0 & 3.73 & 0.01 & 4.30 \\
1 & 3.74 & 0.01 & 4.32 \\
2 & 3.75 & 0.01 & 4.34 \\
3 & 3.76 & 0.01 & 4.37 \\
4 & 3.77 & 0.01 & 4.39 \\
5 & 3.79 & 0.01 & 4.41 \\
6 & 3.80 & 0.01 & 4.43 \\
7 & 3.81 & 0.01 & 4.45 \\
8 & 3.82 & 0.01 & 4.47 \\
9 & 3.83 & 0.01 & 4.50 \\
10 & 3.84 & 0.01 & 4.52 \\
11 & 3.85 & 0.01 & 4.54 \\
12 & 3.87 & 0.01 & 4.56 \\
13 & 3.87 & 0.01 & 4.59 \\
14 & 3.88 & 0.01 & 4.61 \\
15 & 3.89 & 0.01 & 4.63 \\
\hline
\end{tabular}

Fig. 7 and Table 13 shows that there is an inclining movement of the value of social vulnerability threats. Meanwhile, changes in the value of social vulnerability have declined as well as an inclined, yet the calculation has increased quite a long time. This shows that the development of the Islamic State has a relatively small effect on social vulnerability in Southeast Asia. The change in the value of social vulnerability is 0.01 and is categorized as Low Vulnerability. The aspects indicate that the existing social system in Southeast Asia is still strong enough in encountering the influence of ideology and the development of the Islamic State (IS). However, if there is no intervention in the development of the Islamic State (IS) for a long period of time, the value of vulnerability that inclines up will put pressure on the existing social system in Southeast Asian society. This condition certainly has an impact on the social system for the people of Southeast Asia in the future.

\section{Conclusion}

The development of the Islamic State (IS) in Southeast Asia provides changes in the social order in society in direct or indirect manner. It affects the action and activity pattern of society in various aspects, including social aspects. This social condition is regarded to be able to clarify the existing strategic situation in Southeast Asia. Based on the results of research from relevant experts, this study uncovered seven the most dominant and structured problems. Furthermore, there are fourteen elements related to the social vulnerability of the Islamic State (IS) in Southeast Asia.

The budget capability criterion had the highest weight value of 0.286 with a score of 3.865 . Terrorism criteria had the lowest value of 0.122 with a score of 4.585 . The vessel traffic has the highest weighting of 0.490 with a score of 2.430 . The Illegal Transport criterion has the lowest weighting of 0.198 with a score of 3.445 . The criteria for ease of access to finance had the lowest weighting of 0.261 with a score of 4.725 . The criteria for Law and Regulation had the highest weighting of 0.407 with a score of 3.715. Territorial control criteria had the lowest weighting of 0.264 with a score of 4.046.

The influence of Islamic State development on social vulnerability is a system. Hence, it has a network that involves complex variables and dynamics. Thus, system dynamics were used to draw models. Furthermore, weighting was carried out using the AHP and an assessment of a 1-5 point Likert score. Based on the research results, the social vulnerability value is 0.01 and is categorized as Low Vulnerability. The aspects that influence the development of Islamic State indicate that the existing social system in Southeast Asia is strong enough in encountering the influence of ideology and the development of the Islamic State.

\section{Future Work}

a. Further works are expected to establish the intervention from governments in Southeast Asia to minimize the risk of the development of the Islamic State by using risk mitigation strategies.

b. Future studies are expected to provide an analysis of the value of social resilience in Southeast Asian societies to identify the extent of the current social resilience of the ASEAN community.

\section{Acknowledgement}

This study was supported by Indonesia Defense University and National Defence University of Malaysia for integrated research. 


\section{References}

Abdullah, M. R. T. L., Siraj, S., Asra \& Hussin, Z. (2014). Interpretive Structural Modeling of M-Learning Curriculum Implementation Model of English Language Communication Skills for Undergraduates. The Turkish Online Journal of Educational Technology, 13(1), 151-161.

Aldianto, L., Novani, S., Anggadwita, G., Budi, A. A., \& Wirawan, C. (2020). Soft system methodology approach: tourism conceptual model as the identity of Bandung, Indonesia. Business: Theory and Practice, 21(1), 282-292.

Aksha, S. K., Juran, L., Resler, L. M., \& Zhang, Y. (2019). An analysis of social vulnerability to natural hazards in Nepal using a modified social vulnerability index. International Journal of Disaster Risk Science, 10(1), 103-116.

Belim, C. \& Garcia, H. (2016). 'To Be, or Not To Be a Cyberterrorist', That Is the Question! The Political Communication of al-Qaeda and Islamic State on Social Networks. Trípodos, 39, 13-33.

Beran, I. M. (2015). System Dynamics Modelling And Simulating The Effects Of Intellectual Capital On Economic Growth. Croatian Operational Research Review, 6, 445-457.

Bona, G. D. \& Falcone, D. (2019). AHP-TOPSIS Model to Evaluate Maintenance Strategy using RAMS and Production Parameters. International Journal of Operations and Quantitative Management, 25(3), 175-201.

Burton, C. \& Cutter, S. (2008). Levee failures and social vulnerability in the Sacremento- San Joaquin delta area, California. Natural Hazards Review, 9(3), 136-149.

Calabrese, A., Costa, R., Levialdi, N. \& Menichini, T., 2019. Integrating sustainability into strategic decision-making: A fuzzy AHP method for the selection of relevant sustainability issues. Technological Forecasting and Social Change, 193, 155-168.

Chen, W., Cutter, S., Emrich, C. \& Shi, P., 2013. Measuring social vulnerability to natural hazards in the Yangtze River Delta region, China. International Journal of Disaster Risk Science, 4(4), 169-181.

Cutter, S., Boruff, B. \& Shirley, W., 2003. Social vulnerability to environmental hazards. Social Science Quarterly, 84(2), 242-261.

Dekrita, Y. A., Yunus, R., Citta, A. B. \& Yamin, M., 2018. Integration of Balanced Scorecard and Analytical Hierarchy Process as a Tool for Determining the Priority of the Program Strategy: Case Study in Dr.Tc.Hillers Maumere Hospital. s.1., 3rd International Conference on Accounting, Management and Economics.

Dubey, R., Sekaran, A. G. \& Wamba, S. F., 2015. Building Theory of Green Supply Chain Management using Total Interpretative Structural Modeling (TISM). FAC-Papers OnLine, 48(3), 1688-1694.

Emrich, C. \& 2011, S. C. (2011). Social vulnerability to climate-sensitive hazards in the southern United States. Weather, Climate, and Society, 3(3), 193-208..

Enteshari, S. \& Safavi, H., 2021. Development of System Dynamics for Holistic Conceptualization of Water Resources Problems Using Grounded Theory: A Case Study of the Zayandehrud River Basin. Iranian Journal of Science and Technology, Transactions of Civil Engineering, 45, 413-428.

Febriansyah, J., Gernowo, R. \& Kusumawardhani, A., 2017. Implementation of AHP and TOPSIS Method to Determine the Priority of Improving the Management of Government's Assets. International Journal of Innovative Research in Advanced Engineering, 4(3), pp. 46-53.

Forrester, J. W. (1994). Sistem Dynamics, Sistems Thinking, and Soft OR. Sistem Dynamics Review Summer, $10(2), 3$.

Girasole, E. G. d. \& Cannatella, D. (2017). Social Vulnerability to Natural Hazards in Urban Systems. An Application in Santo Domingo (Dominican Republic). Sustainability, 9, 1-17.

Hummell, B. M. d. L., Cutter, S. L. \& Emrich, C. T. (2016). Social Vulnerability to Natural Hazards in Brazil. International Journal Disaster Risk Science, 7, 111-122.

Improta, G., Russo, M. A., Triassi, M., Converso, G., Murino, T., \& Santillo, L. C. (2018). Use of the AHP methodology in system dynamics: modelling and simulation for health technology assessments to determine the correct prosthesis choice for hernia diseases. Mathematical biosciences, 299, 19-27.

Khakbaz, S. \& Hajiheydari, N. (2015). Proposing a basic methodology for developing balanced scorecard by system dynamics approach. Kybernetes, 44(6/7), 1049-1066.

Kumar, A., Sah, B., Singh, A. R., Deng, Y., He, X., Kumar, P., \& Bansal, R. C. (2017). A review of multi criteria decision making (MCDM) towards sustainable renewable energy development. Renewable and Sustainable Energy Reviews, 69, 596-609.

Medineckiene, M., Zavadskas, E., Björk, F. \& Turskis, Z. (2015). Multi-criteria decision-making system for sustainable building assessment/certification. Archives of Civil and Mechanical Engineering, 15(1), 11-18.

Panackal, N. \& Singh, A. (2016). Using Interpretative Structural Modeling to Determine the Relation between Youth and Sustainable Rural Development. Journal of Management and Research, 4(1), pp. 58-64.

Papathoma-Köhle, M., Kappes, M., Keiler, M. \& Glade, T., 2011. hysical vulnerability assessment for alpine hazards: State of the art and future needs. Nat. Hazards, 58, 645-680.

Qiu, Y., Shi, X. \& Shi, C., 2015. A System Dynamics Model for Simulating the Logistics Demand Dynamics of Metropolitans: A Case Study of Beijing, China. Journal of Industrial Engineering and Management, 8(3), $783-803$.

Saaty, T. L. (1980). The Analytical Hierarchy Process. New York: McGraw Hill.

Saaty, T. L. \& Vasgas, L. G. (2006). Decision Making with the Analytical Hierarchy Process (AHP). Pittsburg: Springer Science Bussiness Media. 
Shahabi, A., Azar, A., Radfar, R. \& Asadifard, R. A. (2019). Combining Soft System Methodology with Interpretive Structural Modeling and System Dynamics for Network Orchestration: Case Study of the Formal Science and Technology Collaborative Network in Iran. Systemic Practice and Action Research, 1-16.

Simidjievski, N., Todorovski, L. \& Džeroski, S. (2016). Modeling Dynamic Systems with Efficient Ensembles of ProcessBased Models. PLoS ONE, 11(4), 1-27.

Song, Y. \& Yang, J.-h., 2015. Simulation of Dynamics Behaviors for Shipping Equipment Support with System Dynamics Analysis Approach. Journal of Industrial Engineering and Management, 8(3), 636-657.

Sterman, J. D., Henderson, R., Beinhocker, E. \& Newman, L., 2007. Getting big too fast:strategic dynamics with increasing returns and bounded rationally. Management Science, 53(4), 683-696.

Sushil (1993). System Dynamics : A Practical Approach for Managerial Problems. s.1.:Wiley Eastern Limited.

Susilo, A. K., Ciptomulyono, U., Putra, I. N., Ahmadi, A., \& Suharyo, O. S. (2019). Navy Ability Development Strategy using SWOT Analysis-Interpretative Structural Modeling (ISM). Strategic Management-International Journal of Strategic Management and Decision Support Systems in Strategic Manage, 24(1), pp. 30-40.

Tobing, F. B. L. \& Indradjaja, E. (2019). Islamic State In Iraq And Syria (ISIS) And Its Impact In Indonesia. Global: Jurnal Politik Internasional, 21(1), 101-125.

Tome, L. (2015). The "Islamic State": Trajectory and Reach A Year After Its Self-Proclamation As A "Caliphate". e-journal of International Relations, 6(1), 116-139.

Vachnadze, R. (2016). Priorization of Performance Measures using Analytical Hierarchy Process. International Journal of the Analytic Hierarchy Process, 8(3), 408-501.

Wang, S., Wang, G. \& Zhang, J. (2019). Data Analysis Method Of Terrorist Attacks Based On AHP-DBSCAN Method. Journal of Physics, 1168, 1-8.

Wang, X. \& Duan, Q. (2019). Improved AHP-TOPSIS Model for The Comprehensive Risk Evaluation of Oil And Gas Pipelines. Petroleum Science, 16, 1479-1492.

Wua, W., Kou, G. \& Peng, Y. (2016). Group Decision-Making Using Improved Multi-Criteria Decision Making Methods for Credit Risk Analysis. Filomat, 30(15), 4135-4150.

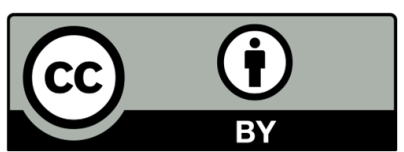

(C) 2021 by the authors; licensee Growing Science, Canada. This is an open access article distributed under the terms and conditions of the Creative Commons Attribution (CC-BY) license (http://creativecommons.org/licenses/by/4.0/). 